\title{
PRIVATE ENFORCEMENT UNDER RULE 10b-5: AN INJUNCTION FOR A CORPORATE ISSUER?
}

One of the most difficult problems which has confronted courts in interpreting the securities acts has been the degree to which private remedies should be afforded for their enforcement. The plaintiff in Studebaker Corp. v. Allied Products Corp. ${ }^{1}$ sought to expand the scope of private enforcement of section 10(b) of the Securities Exchange Act of $1934,{ }^{2}$ contending that a corporate issuer of stock has the right under SEC rule $10 \mathrm{~b}-5^{3}$ to enjoin manipulation of its securities.

Studebaker alleged that defendants ${ }^{4}$ had conspired to gain control of Studebaker by means of "fraudulent and unlawful acts in violation of the Exchange Act." 5 After Studebaker's rejection of a merger proposal, defendants initiated a campaign designed to wrest control of the company's board of directors. Defendants allegedly filed misleading proxy materials in violation of section 14(a) of the Exchange Act of $1934^{6}$ and, through allegedly false representations, artificially distorted the market price of Studebaker stock in violation of sections $9(\mathrm{a})^{\top}$ and $10(\mathrm{~b})$ of the act. The district court dismissed Studebaker's claim for injunctive relief under section 10, applying the traditional doctrine that only purchasers or sellers are entitled to bring private

1256 F. Supp. 173 (W.D. Mich. 1966).

248 Stat. 891 (1934), 15 U.S.C. \$78j (b) (1964) :

It shall be unlawful for any person, directly or indirectly, by the use of any means or instrumentality of interstate commerce or of the mails, or of any facility of any national securities exchange-

(b) To use or employ, in connection with the purchase or sale of any security registered on a national securities exchange or any security not so registered, any manipulative or deceptive device or contrivance in contravention of such rules and regulations as the Commission may prescribe as necessary or appropriate in the public interest or for the protection of investors.

317 C.F.R. $\$ 240.10 \mathrm{~b}-5$ (1964) :

It shall be unlawful for any person, directly or indirectly, by the use of any means or instrumentality of interstate commerce, or of the mails or of any facility of any national securities exchange,

(a) To employ any device, scheme, or artifice to defraud,

(b) To make any untrue statement of a material fact or to omit to state a material fact necessary in order to make the statements made, in the light of the circumstances under which they were made, not misleading, or

(c) To engage in an act, practice, or course of business which operates or would operate as a fraud or deceit upon any person, in connection with the purchase or sale of any security.

4 The defendants were a corporation, a brokerage house and an individual senior partner of the brokerage house.

5 Brief for Appellant, p. 3, Studebaker Corp. v. Allied Prods. Corp., No. 17253, 6th Cir., May 25, 1966, appeal dismissed, New York Times, Dec. 31, 1966, p. 27, col. 3. 648 Stat. 895 (1934), as amended, 15 U.S.C. $\$ 78 n$ (a) (1964).

748 Stat. 889 (1934), 15 U.S.C. $\$ 78 \mathrm{i}($ a) (1964). 
actions under section 10 and rule $10 \mathrm{~b}-5 .^{8}$ Evidence was taken as to the alleged violation of section 14(a) and, although the court refused to enjoin the solicitation of proxies, it did order that the proxy contest be supervised by the court. ${ }^{9}$

On appeal to the Sixth Circuit, Studebaker urged a novel argument opposing dismissal of the complaint under section $10(\mathrm{~b})$, contending (1) that as an issuer of stock, it "has a duty to maintain the market [for its stock] . . . free from manipulative distortion," ${ }^{10}$ (2) that defendants, through their misrepresentations, were distorting the market in contravention of rule $10 \mathrm{~b}-5$, and (3) that the rationale of J. I. Case Co. v. Borak ${ }^{11}$ and Studebaker Corp. v. Gittlin ${ }^{12}$ allows a corporation to enforce the federal securities regulations through injunctive relief. Judicial acceptance of this argument would significantly broaden private $10 \mathrm{~b}-5$ actions. Studebaker's appeal was dismissed, however, when the parties settled their dispute out of court. ${ }^{13}$

The district court held that Studebaker lacked standing to bring the 10b-5 action because it was neither a purchaser nor a seller of securities. ${ }^{14}$ The language of rule $10 \mathrm{~b}-5$-that it is unlawful to use deception or fraud "in connection with the purchase or sale of any security" ${ }^{15}$ - was the basis for this decision. The right of a private party to maintain an action under section $10(\mathrm{~b})$, as well as the restriction of parties to purchasers or sellers, stems from decisional law and has been applied only in actions for damages caused by a rule $10 \mathrm{~b}-5$ violation. ${ }^{16}$ To determine whether this limitation should be applied against a corporate issuer seeking injunctive relief, it is necessary to examine its origin.

Section 10 of the Exchange Act does not provide for enforcement, either by private parties or the Securities and Exchange Commission; it merely states that certain activities proscribed by the SEC shall be unlawful. The enforcement power for section 10 is found in section 21(e), ${ }^{17}$ which permits the SEC to transmit evidence of violations

8256 F. Supp. at $179-80$.

$\checkmark$ Id. at $188-90$.

10 Brief for Appellant, p. 28, Studebaker Corp. v. Allied Prods. Corp., No. 17253, 6th Cir., May 25, 1966, appeal dismissed, New York Times, Dec. 31, 1966, p. 27, col. 3. 11377 U.S. 426 (1964) (derivative action for damages and rescission of merger sustained where defendants had acquired shareholder approval through a misleading proxy statement in violation of $\$ 14(\mathrm{a})$ ).

12360 F.2d 692 (2d Cir. 1966) (injunction upheld which prohibited use of stockholder authorizations acquired through means in violation of $\$ 14(\mathrm{a})$ ).

13 New York Times, Dec. 31, 1966, p. 27, col. 3.

14 Studebaker Corp. v. Allied Prods. Corp., CCH FED. Skc. L. REP. 1191,669 , at 95,459, aff'd an reconsideration, 256 F. Supp. 173, 179-80 (W.D. Mich. 1966).

1517 C.F.R. \$240.10b-5 (1964).

16 See, e.g., Kardon v. National Gypsum Co., 69 F. Supp. 512 (E.D. Pa. 1946), modified, 73 F. Supp. 798 (E.D. Pa. 1947).

1748 Stat. 899 (1934), as amended, 15 U.S.C. $\$ 78 u(e)$ (1964) :

(e) Whenever it shall appear to the Commission that any person engaged or about to engage in any acts or practices which constitute or will consti- 
to the Attorney General for prosecution and gives the SEC power to bring an action to enjoin violations. Section $27,{ }^{18}$ which grants exclusive jurisdiction to the district courts for "all suits in equity and actions at law brought to enforce any liability or duty created by this chapter or the rules or regulations thereunder," 19 is the jurisdictional basis for private section 10 actions. In 1946, a private party for the first time was allowed to maintain a damage action for a rule $10 \mathrm{~b}-5$ violation, upon showing that he was defrauded into selling his stock for an amount substantially less than its worth. ${ }^{20}$ The district court noted that no private party actions were explicitly provided for by the act for a section 10 violation, but held that injury stemming from the violation of a statute was an actionable tort ${ }^{21}$ and that section 27 implied that there would be federal jurisdiction for such suits. ${ }^{22}$

A limit on the use of $10 \mathrm{~b}-5$ in private actions was judicially imposed in 1952 in Birnbaum v. Newport Steel Corp. ${ }^{23}$ Newport's directors allegedly rejected a favorable merger offer and then sold their majority control of the company at a large premium. Specific acts of fraud were alleged: it was charged that defendants made misrepresentations in letters to Newport shareholders both at the time of the merger negotiations and after the sale of control. The district court dismissed the case for failure to state a cause of action, and the Second Circuit affirmed on two grounds: (1) private actions under rule $10 \mathrm{~b}-5$ may only be brought by a person who has bought or sold, ${ }^{21}$

tute a violation of the provisions of this chapter, or of any rule or regulation thereunder, it may in its discretion bring an action in the proper district court of the United States or the United States courts of any Territory or other place subject to the jurisdiction of the United States, to enjoin such acts or practices, and upon a proper showing a permanent or temporary injunction or restraining order shall be granted without bond. The Commission may transmit such evidence as may be available concerning such acts or practices to the Attorney General, who may, in his discretion, institute the necessary criminal proceedings under this chapter.

1848 Stat. 902 (1934), as amended, 15 U.S.C. §78aa (1964).

19 Ibid.

20 Kardon v. National Gypsum Co., 69 F. Supp. 512 (E.D. Pa. 1946), modified, 73 F. Supp. 798 (E.D. Pa. 1947).

21 See 2 Restatement (Second), Torts \$286 (1965):

The court may adopt as the standard of conduct of a reasonable man the requirements of a legislative enactment or an administrative regulation whose purpose is found to be exclusively or in part

(a) to protect a class of persons which included the one whose interest is invaded, and

(b) to protect the particular interest which is invaded, and

(c) to protect that interest against the kind of harm which has resulted, and

(d) to protect that interest against the particular hazard from which the harm results.

22 Kardon v. National Gypsum Co., 69 F. Supp. 512, 513 (E.D. Pa. 1946), modified, 73 F. Supp. 798 (E.D. Pa. 1947).

23193 F.2d 461 (2d Cir.), cert. denied, 343 U.S. 956 (1952), criticized in Leech, Transactions in Corporate Control, 104 U. PA. L. REv. 725, 832-35 (1956).

24193 F.2d at 463. 
and (2) the breach of fiduciary duty complained of was not the type of evil intended to be covered by the act. ${ }^{25}$

The second ground for decision in Birnbanm-that section 10 (b) "was directed solely at that type of misrepresentation or fraudulent practice usually associated with the purchase or sale of securities rather than at fraudulent mismanagement of corporate affairs" 28 has generally been accepted by the courts, ${ }^{27}$ reflecting both a reluctance of federal courts to preempt areas of traditional state law concern ${ }^{28}$ and an attempt to restrict $10 \mathrm{~b}-5$ actions to cases where the securities transaction plays a major role in the fraudulent scheme.

This second holding in Birnbaum might appear applicable to the Studebaker facts, but the district court did not consider this question. Although the transactions were part of a proxy battle for control of the corporation, a matter typically regulated by state law, an abuse of the securities trading process was still at the heart of the transaction, ${ }^{29}$ and the remedies provided by state law to correct such abuses are generally inadequate. ${ }^{30}$ It would frustrate the policy of the 1934 act if rule 10b-5 were denied application in a case where a securities transaction was an integral part of the fraud merely because some encroachment upon state law would be necessary. ${ }^{31}$ Moreover, section 28(a) of the Exchange Act ${ }^{32}$ permits a remedy under the act in addition to any state and other federal remedies. ${ }^{33}$

A principal objection to Studebaker's standing stems from management's possible motives. Arguably, Studebaker management brought the $10 \mathrm{~b}-5$ action primarily to preserve its own control, rather than to protect its shareholders. If this were so, it would seem inappropriate to allow management to use the corporation's name and resources for its own preservation. ${ }^{34}$ However, this objection could

$25 I d$. at 464 .

26 Ibid.

27 See O'Neill v. Maytag, 339 F.2d 764, 768 (2d Cir. 1964); Chashin v. Mencher, 255 F. Supp. 545, 548 (S.D.N.Y. 1965); Keers \& Co. v. American Steel \& Pump Corp., 234 F. Supp. 201, 203 (S.D.N.Y. 1964) ; Kremer v. Selheimer, 215 F. Supp. 549, 552 (E.D. Pa. 1963); cf. Ruckle v. Roto Am. Corp., 339 F.2d 24, 28 (2d Cir. 1964); New Park Mining Co. v. Cranmer, 225 F. Supp. 261, 266 (S.D.N.Y. 1963).

28 Leech, Transactions in Corporate Control, 104 U. PA. L. Rev. 725, 834 (1956).

29 See $i d$. at 835.

303 Loss, Securities Regulation 1430-35 (2d ed. 1961) ; Fleischer, "Federal Corporation Law": An Assessment, 78 HARv. L. Rev. 1146, 1175 (1965).

31 O'Neill v. Maytag, 339 F.2d 764, 768 (2d Cir. 1964) (dictum); cf. Voege v. American Sumatra Tobacco Corp., 241 F. Supp. 369, 375 (D. Del. 1965).

3248 Stat. 903 (1934), 15 U.S.C. \$ 78bb(a) (1964): "The rights and remedies provided by this chapter shall be in addition to any and all other rights and remedies that may exist at law or in equity ...."

33 Matheson v. Armbrust, 284 F.2d 670, 673 (9th Cir. 1960). See Voege v. American Sumatra Tobacco Corp., 241 F. Supp. 369, 375 (D. Del. 1965) : "Where . . federal rights are concerned this Court is free to fashion federal law regardless of "state corporation law."

${ }^{34}$ Cf. Cheff v. Mathes, 41 Del. Ch. 494, 199 A.2d 548 (1964); Kors v. Carey, 39 Del. Ch. 47, 158 A.2d 136 (1960); Martin v. Am. Potash \& Chem. Corp., 33 Del. Ch. 234, 92 A.2d 295 (1952). 
be met by denying standing where the motive of the corporate officers is improper, while leaving open the possibility of corporate standing to enjoin rule $10 \mathrm{~b}-5$ violations where there is a legitimate corporate purpose. $^{35}$

In dismissing the $10 \mathrm{~b}-5$ action in Studebaker, the district court relied on the first holding in Birnbaum that such actions are limited to purchasers and sellers. The Birnbaum court supported its holding by examining the language of rule $10 \mathrm{~b}-5$, concluding that it was "abundantly clear" ${ }^{36}$ that the legislative history limited actions to persons who had either bought or sold. The court held that since section 17 (a) of the 1933 act ${ }^{37}$ prohibited only frauds "upon the purchaser" of securities and the SEC release announcing promulgation of rule $10 \mathrm{~b}-5$ expressed an intent to close this loophole, ${ }^{38}$ the "only purpose" of section $10(\mathrm{~b})$ was to give sellers the same protection as purchasers.

This interpretation assumed that the words "any person" were synonymous with "purchaser and seller" and that Congress intended nothing more than to close the loophole in the 1933 act. The plaintiff in Birnbaum argued that the "in connection with" clause exhibited a congressional intent to make unlawful all deceitful conduct affecting any person when a securities transaction was involved. The 1933 act makes unlawful fraud "in the offer or sale of any securities." 39 If the 1934 act were intended only to close the loophole, Congress could have prohibited fraudulent practices "in a purchase or sale, or an offer to purchase or sell any securities." But, instead, language of considerably broader scope- "in connection with the purchase or sale of any security"-was employed. Nonetheless, the district court in Birnbaum dismissed plaintiff's argument, insisting that the statute was not designed to cover the injury alleged.

The court's interpretation of the legislative history has been strongly criticized. ${ }^{40}$ The fact that the SEC release announced an

35 It will often be difficult for a court to determine the true motive of management; in the usual case management will be able to adduce a colorable corporate purpose to support its actions. This might be resolved in part by presuming that management in a proxy battle is motivated by self-interest, therefore shifting the burden to them to prove that their motives are proper. Cf. Cheff v. Mathes, supra note 34 . In any event, it is recognized that some parties will obtain standing who should not have it. Nonetheless, the advantages of injunctive corporate enforcement of $10 \mathrm{~b}-5$ outweigh the disadvantage of having some improper parties.

36 Birnbaum v. Newport Steel Corp., 193 F.2d 461, 463 (2d Cir. 1952).

3748 Stat. 84 (1933), as amended, 15 U.S.C. $\$ 77 q(a)$ (1964).

38 SEC Exchange Act Release No. 3230 (May 21, 1942).

3948 Stat. 84 (1933), as amended, 15 U.S.C. $\$ 77 q(a)$ (1964).

40 Leech, supra note 28, at 833; Comment, 32 TExas L. REv. 197, 206-07 (1953) ; Comment, 100 U. PA. L. REv. 1251, 1253 n.17 (1952). See McManus v. Jessup \& Moore Paper Co., 5 S.E.C. Judicial Decisions 810 (E.D. Pa. 1948) (motion to dismiss denied without opinion where complaint alleged violations of $10 \mathrm{~b}-5$ under circumstances similar to those in Birnbaum). See also Voege v. American Sumatra Tobacco Corp., 241 F. Supp. 369, 372 n.3a (D. Del. 1965), which casts some doubt on the purchaserseller limitation of Birnbann by noting that its decision was made without either affirming or rejecting Birnbanm's interpretation of $10 \mathrm{~b}-5$. 
intent to close the loophole should not foreclose a broader interpretation, and certainly it is not conclusive evidence of congressional intent. At most, it has been said, the plight of injured parties who were not purchasers or sellers was not considered by Congress. ${ }^{41}$ Nonetheless, many courts have blindly followed Birnbanm's purchaser-seller limitation without further consideration of the criticism which it has engendered. ${ }^{42}$

Several recent cases, allowing "aborted sellers" to maintain actions when there was no sale prompted by the fraud, have begun to expand the reach of the "in connection with" clause. ${ }^{43}$ In Stockwell v. Reynolds \& Co., ${ }^{44}$ the plaintiff was induced by his broker's misrepresentations to retain a poor investment. After later discovering the truth and selling, Stockwell sued under section 10 to recover his loss. The court rejected the defendant's claim that the misrepresentation was not made as part of a purchase or sale, reasoning that injury had resulted from a fraud in connection with a sale, and that such a holding furthered the intent of the act "to protect the investors against fraud." ${ }_{45}$ In $M$. L. Lee \& Co. v. American Cardboard \& Packaging Corp., ${ }^{46}$ an underwriter's refusal to purchase stock as agreed in an underwriting contract was held actionable under rule $10 \mathrm{~b}-5$ as fraud "in connection with" a sale of securities. The court held that an actual sale was not necessary and that fraud affecting a contract to sell was within the scope of rule $10 \mathrm{~b}-5 .{ }^{47}$

The "in connection with" clause was also liberally construed in Voege v. American Sumatra Tobacco Corp. ${ }^{48}$ Plaintiff did not tender his shares pursuant to a tender offer and, at the time of the litigation, had yet to sell. However, when the offeror, through allegedly fraudulent statements, had acquired enough shares to effect a short-form merger with a dummy corporation, plaintiff became obligated under Delaware law to sell his stock to the merged company either at the

41 Comment, 100 U. PA. L. REv. 1251, 1253 n.17 (1952).

42 See, e.g., Hoover v. Allen, 241 F. Supp. 213, 223 (S.D.N.Y. 1965) ; Cooper v. North Jersey Trust Co., 226 F. Supp. 972, 978 (S.D.N.Y. 1964).

43 But see DeGatano v. Steele, CCH FED. SEC. L. REP. $\pi 91,671$ (S.D.N.Y. Apr. 22, 1966) (action denied to a nonselling shareholder for damages suffered by his inability to sell his stock because the defendant, through deceit, had caused nontransferrable stock to be issued to shareholders in place of negotiable securities); Keers \& Co. v. American Steel \& Pump Corp., 234 F. Supp. 201 (S.D.N.Y. 1964); see discussion in Fleischer \& Mundheim, Corporate Acquisition by Tender Offer, 115 U. PA. L. Rev. 317, 361 n.176 (1967).

4252 F. Supp. 215 (S.D.N.Y. 1965). It is arguable, however, that this is not an "aborted seller" case since Stockwell eventually sold his stock and the fraud continued until the sale.

$45 I d$. at 219.

4636 F.R.D. 27 (E.D. Pa. 1964).

47 The court based its holding on $\$ 3(a)$ (14) of the Exchange Act, 48 Stat. 882 (1934), as amended, 15 U.S.C. $\$ 78 \mathrm{c}(\mathrm{a})(14)$ (1964), which includes "a contract to sell" in its definition of "a sale."

48241 F. Supp. 369 (D. Del. 1965). Cf. Vine v. Beneficial Fin. Co., No. 30500, 2d Cir., March 13, 1967. The court found it unnecessary to consider the SEC's amicus argument that one need not be a selling shareholder to sue under $10 \mathrm{~b}-5$, 
tender price or at an amount determined through an appraisal. The court, in finding standing under $10 \mathrm{~b}-5$, held that since a shareholder upon purchase of his shares contracts by state law to sell upon demand to the survivor of a short-form merger, any fraud affecting that contract was in connection with plaintiff's "sale":

The frauds allegedly perpetrated upon plaintiff were, in a very real sense, related to a vital part of the contract . . . under which plaintiff had agreed to sell. They were committed "in connection with the purchase [and] . . . sale" of a security within the meaning of Rule 10b-5. Any other view of the transaction would defeat the purpose of Rule $10 \mathrm{~b}-5 \ldots .{ }^{49}$

Although the foregoing cases might be distinguishable from third-party cases in that the former concerned frauds affecting would-be parties to securities transactions, these cases nonetheless evidence a judicial willingness to broaden the strict purchaser-seller limitation expressed in Birnbaum.

A strong argument for the strict purchaser-seller limitation has been that if a third party to a transaction should recover damages suffered by the purchaser or seller, he would be unjustly enriched. Kremer $v$. Selheimer ${ }^{50}$ is representative of this argument. Plaintiff, a receiver in bankruptcy, alleged that the company was defrauded when defendant officers bought shares from the company below market price and sold them at a price inflated through the fraud of the broker. The court dismissed a damage action because the injury was to the purchasers, not the corporation:

[T] he amended complaint fails to place [plaintiff] . . . in the category of defrauded seller and it is, therefore, fatally deficient. [Plaintiff] . . has misconstrued the scope and purpose of Section 10(b) and Rule 10b-5. His construction would entitle . . the issuing corporation to claim the fruits of the fraud and deception which he contends was practiced by defendants on purchasers of [its] . . . stock. I read no intent in the legislation or the Rule to confer such a benefit on the issuing corporation. ${ }^{61}$

This basis for retaining the Birnbaum limitation has also been questioned. In Pettit v. American Stock Exch., ${ }^{52}$ a corporate cause

49241 F. Supp. at 374.

50215 F. Supp. 549 (E.D. Pa. 1963) ; accord, Defiance Indus., Inc. v. Galdi, 256 F. Supp. 170 (S.D.N.Y. 1964) (damage action against a broker for injury to corporation by statements derogatory to company, forcing the stock price down).

$51215 \mathrm{~F}$. Supp. at 553. (Emphasis added.)

52217 F. Supp. 21 (S.D.N.Y. 1963). 
of action for damages was successful where defendants allegedly violated rule $10 \mathrm{~b}-5$ in connection with two distributions of a corporation's securities: in the first the corporation issued stock in exchange for worthless assets, and in the second the stock was then distributed to the public on an allegedly rigged market. Defendants challenged the corporate cause of action as to the second transaction, claiming that the injury was to the investors, not to the corporation. The court upheld federal jurisdiction under rule $10 \mathrm{~b}-5$, noting that both transactions were part of a continuous scheme to defraud the company. In significant dicta the court added:

[T] he elements of this case make it particularly appropriate for the recognition of federal rights of the corporation. . . . Defendants appear to concede that investors in Swan-Finch stock may have been damaged by their acts, and that appropriate Section 10 (b) liability would lie in such cases. This concession offers only a limited solution to the defrauded parties, as there are serious practical obstacles to the successful prosecution of a lawsuit on behalf of an extremely large and scattered class of persons, each of whose potential recovery is limited. . . . In view of these facts, it is clear that the inclusion of this cause of action within Section 10(b) represents a warranted exercise of federal jurisdiction in an effort to accomplish what Congress intended-the protection of the integrity of stock transactions. ${ }^{53}$

Even if the Birnbaum purchaser-seller limitation is valid in damage suits, it cannot justifiably be applied in an action to enjoin a $10 \mathrm{~b}-5$ violation. The tenor of the Exchange Act is prophylactic, and its intent is to prevent securities frauds. ${ }^{54}$ Injunctions are surely an appropriate remedy to maintain a fair and honest stock market and are the only method of preventing injury to innocent investors. The chief argument, other than possible intrusion upon state law, against allowing a third party to sue in damage actions-that there would be unjust enrichment to the third party ${ }^{55}$-is clearly inapplicable in an injunction case.

It might be urged that a legislative decision was made, and expressed in section $21(\mathrm{e}),{ }^{56}$ to vest exclusive power in the SEC to

53 Id. at $27-28$.

54 The House Resolution calling for regulation of the securities exchanges proclaimed that the 1934 act would "prevent inequitable and unfair practices on [stock] exchanges." H.R. Res. 363, 73d Cong., 2d Sess. (1934). Section 2 of the Exchange Act, entitled "Necessity for Regulation," explains that the act is "to insure the maintenance of fair and honest markets in [stock] transactions." 48 Stat. 881 (1934), 15 U.S.C. \$78b (1964).

55 See Kremer v. Selheimer, 215 F. Supp. 549 (E.D. Pa. 1963) ; text accompanying notes $50-51$ supra.

5648 Stat. 899 (1934), as amended, 15 U.S.C. $\$ 78 \mathrm{u}(\mathrm{e})$ (1964). The text of $\$ 21(\mathrm{e})$ is quoted in note 17 supra. 
enforce the act through injunctive relief. ${ }^{57}$ But there is little support for such a position, since the act neither specifically limits injunctive relief to the SEC nor excludes private parties. Courts have rejected similar expressio unius est exclusio alterius ${ }^{58}$ arguments in litigation concerning standing under the Exchange Act.59 Indeed, the 1964 case of Ruckle $v$. Roto American Corp ${ }^{60}$ permitted standing to a private party seeking injunctive relief in a $10 \mathrm{~b}-5$ action. In reversing the district court, the Second Circuit held that the plaintiff had standing to enjoin a stock issuance which allegedly was the product of fraud by a majority of the board of directors:

[I] $t$ is far more likely that, as a result of the fraud perpetrated upon the corporation, overvalued stock may reach the market.

Of course, it was precisely the fear that such securities would be publicly distributed which prompted Congress to enact the federal securities laws. ${ }^{61}$

Strong support for granting standing to a corporation seeking equitable relief is found in the proxy area. In J.I. Case Co. v. Borak, ${ }^{62}$ plaintiff alleged that a merger was approved only because of the dissemination of false and misleading materials by the board of directors. The Supreme Court refused to dismiss the case though defendant urged that no private action existed under section 14:

Private enforcement of the proxy rules provides a necessary supplement to Commission action. As in anti-trust treble damage litigation, the possibility of civil damages or injunctive relief serves as a most effective weapon in the enforcement of the proxy requirements. ${ }^{63}$

The corporation is thus cast in the role of a policeman helping the SEC to enforce the proxy rules. The Borak Court also emphasized the difficulty that the SEC faces in trying to uncover all violations of the act, ${ }^{64}$ and stressed the necessity of providing effective remedies:

57 Cf. Goldsmith v. Western \& So. Life Ins. Co., 5 S.E.C. Judicial Decisions 795 (N.D. Ohio 1948) (private plaintiff held to have no right to sue under $\$ 21(\mathrm{e})$ ). 58 "Expression of one thing is the exclusion of another." BLACK, LAw DicrionARY 692 (4th ed. 1951). The argument is that since Congress specifically allowed the SEC to seek injunctive relief and did not mention private injunctive suits, Congress intended that private parties be excluded.

59 See Kardon v. National Gypsum Co., 69 F. Supp. 512 (E.D. Pa. 1946), modified, 73 F. Supp. 798 (E.D. Pa. 1947) ; 2 Loss, SEcuritres Regulation 937-46 (2d ed. 1961) ; Fleischer, "Federal Corporation Law": An Assessment, 78 Harv. L. REv. 1146, 1158 (1965); 12 U.C.L.A.L. REv. 1150, 1156-57 (1965); 31 U. Crr. L. REv. 328, 335-36 (1964); cf. SEC v. C. M. Joiner Leasing Corp., 320 U.S. 344, 350-51 (1943) ; Dann v. Studebaker-Packard Corp., 288 F.2d 201, 208-10 (6th Cir. 1961), criticized in Ruder, Civil Liability Under Rule 10b-5: Judicial Revision of Legislative Intent?, 57 Nw. U.L. REv. 627 (1963).

60339 F.2d 24 (2d Cir. 1964).

61 Id. at 28.

62377 U.S. 426 (1964).

$63 I d$. at 432 .

64 Id. at 432-33. See also Fleischer \& Mundheim, Corporate Acquisition by Tender Offer, 115 U. PA. L. Rev. 317, 360-61 (1967). 
We, therefore, believe that under the circumstances here it is the duty of the courts to be alert to provide such remedies as are necessary to make effective the congressional purpose. . . . It is for the federal courts "to adjust their remedies so as to grant the necessary relief" where federally secured rights are invaded. "And it also well settled that where legal rights have been invaded, and a federal statute provides for a general right to sue for such invasion, federal courts may use any available remedy to make good the wrong done." 65

Borak was expansively interpreted in Studebaker Corp. v. Gittlin, ${ }^{66}$ where a corporation was, in effect, permitted the same enforcement powers as the SEC in a suit to enjoin a proxy violation. Defendants had solicited authorizations from shareholders to be used in a New York state court action to obtain a shareholders list. The court held that such a solicitation, without a prior filing with the SEC, violated the proxy rules. In discussing whether the federal anti-injunction statute ${ }^{67}$ should bar private actions to enjoin proxy violations, the Second Circuit refused to distinguish between enforcement by the SEC and by a private party:

If the policy of the anti-injunction statute is superseded by the need for immediate and effective enforcement of federal securities regulations and statutes, the fact that enforcement here is by a private party rather than the agency should not be controlling. The Surpeme Court has recognized such a suit as being "a necessary supplement to Commission action" in providing the protection for investors contemplated by the statute. ${ }^{.8}$

The fact that little or no damage was proved in Gittlin was not deemed decisive ${ }^{69}$ and did not prevent private injunctive relief as an adjunct to SEC action. ${ }^{70}$

65377 U.S. at 433, quoting in part from Bell v. Hood, 327 U.S. 678, 684 (1946).

86360 F.2d 692 (2d Cir. 1966). Gittlin was a related proceeding to the Studebaker case, both concerning a proxy battle for control of the Studebaker Corporation. 6728 U.S.C. \$2283 (1964).

68360 F.2d at 698 , quoting in part from J. I. Case Co. v. Borak, 377 U.S. 426, 432 (1964).

69 The court noted that a discussion of "irreparable injury . . . generally produces more dust than light," 360 F.2d at 698, and continued:

A plaintiff asking an injunction because of the defendant's violation of a statute is not required to show that otherwise rigor mortis will set in forthwith; all that "irreparable injury" means in this context is that unless an injunction is granted, the plaintiff will suffer harm which cannot be repaired. At least that is enough where, as here, the only consequence of an injunction is that the defendant must effect a compliance with the statute which he ought to have done before. . . . [T] considered that the public interest in enforcing the Proxy Rules outweighed any inconvenience to Gittlin in having to start again.

Ibid. (Emphasis added.)

70 But cf. Barnett v. Anaconda Co., 238 F. Supp. 766 (S.D.N.Y. 1965), which dismissed an action because there was no causal relationship between the alleged 
The line of reasoning by which the Borak and Gittlin courts found that equitable relief to enforce section 14(a) was proper is equally applicable to section $10(\mathrm{~b})$. Both sections proscribe unfair and undesirable practices which prevailed in securities transactions prior to the act. If a private party may help the SEC police one, it should be able to help police the other. The structure of the two sections is also similar: section $10(\mathrm{~b})$ makes it unlawful to employ any "manipulative or deceptive device or contrivance" in securities transactions "in contravention of such rules and regulations as the Commission may prescribe as necessary or appropriate in the public interest or for the protection of investors"; ${ }^{71}$ section 14(a) declares it unlawful to solicit proxies "in contravention of such rules and regulations as the Commission may prescribe as necessary or appropriate in the public interest or for the protection of investors." 72 To hold that the Borak rationale cannot extend to section $10(\mathrm{~b})$ and that the standing granted in the Ruckle case is incorrect would not be consonant with the general trend of recent decisions in the securities area which have favored an expansive interpretation of the act to eliminate undesirable practices. ${ }^{73}$

There are several sound policy arguments for allowing a corporate issuer to maintain an action for injunctive relief in rule $10 \mathrm{~b}-5$ cases. The corporation is in a markedly better position to protect its shareholders' interests than are the shareholders themselves. The corporation's managers have current information as to the value of the corporate assets and such factors as estimated future earnings which tend to determine market price. They also will probably be the first to recognize an illegal manipulation of the stock. The corporation is also better able financially to bring a suit promptly before substantial damage is done to the shareholders. ${ }^{74}$

Although the injured or potentially injured party may have an adequate remedy at law for damages subsequent to the fraud, an injunc-

violation of $\S 14(a)$ and the injury claimed. Defendant owned $73 \%$ of the outstanding shares of the corporation and any misleading material in the proxy statement would not affect a merger vote even if the minority were deceived. The court's reasoning is questionable because a full disclosure might have provoked a minority suit for an accounting which could have forced the exchange rate of the stock to such a level that defendant would not have gone through with the merger.

7148 Stat. 891 (1934), 15 U.S.C. \$78j(b) (1964).

7248 Stat. 895 (1934), as amended, 15 U.S.C. $\$ 78 \mathrm{n}$ (a) (1964).

73 See, e.g., Hooper v. Mountain States Sec. Corp., 282 F.2d 195 (5th Cir. 1960), cert. denied, 365 U.S. 814 (1961) (an "issuer" determined to be a "seller" for the purposes of rule 10b-5 litigation); Note, Civil Liability Under Section 10(b) and Rule 10b-5, 74 YaLe L.J. 658 (1965). See also the many recent cases in which privity of contract was not required to maintain a $10 \mathrm{~b}-5$ action. Cooper v. North Jersey Trust Co., 226 F. Supp. 972 (S.D.N.Y. 1964); Pettit v. American Stock Exch., 217 F. Supp. 21 (S.D.N.Y. 1963) ; Cochran v. Channing Corp., 211 F. Supp. 239 (S.D.N.Y. 1962) ; Texas Continental Life Ins. Co. v. Dunne, 307 F.2d 242, 249 (6th $\mathrm{Cir}$ 1962) (dictum). The continued expansion of corporate common law under the Exchange Act is predicted in Ruder, Civil Liability Under Rule 10b-5: Judicial Revision of Legislative Intent?, 57 Nw. U.L. Rev. 627, 685 (1963).

74 See Ruckle v. Roto Am. Corp., 339 F.2d 24, 28 (2d Cir. 1964). 
tion is an appropriate corporate remedy. It is far better to allow one injunctive proceeding, than perhaps scores of individual damage suits after the fact. ${ }^{7 \overline{5}}$ Furthermore, the Exchange Act of 1934 was designed to prevent manipulation and frauds; ${ }^{\mathbf{7 6}}$ damage actions are an outgrowth from the act to compensate those who have been injured when the damage was not prevented. ${ }^{77}$

In the Ruckle case, a derivative suit to enjoin issuance of securities although the damage would be to the shareholders, the court recognized the necessity of the corporate action:

Barring suit by a corporation defrauded under those circumstances would, as a legal and practical matter, destroy any remedy against the perpetrator of the frand. Suits by individual shareholders would either run afoul of privity requirements . . . or result in smaller recoveries based on loss to individual investments, which would also be difficult to compute. $^{78}$

Further support for the corporation's right of action comes from the fact that the company is often irreparably injured by a manipulation of its stock. An artificial depression of the market price would hamper any merger negotiations then in progress, could cause termination of or loss in an issuance of stock and would interfere with the corporation's ability to raise funds by borrowing against treasury shares. A manipulation of the price upward could also interfere with the raising of capital or with other corporate activities.

If it is concluded that a corporation does have standing to sue, courts will then have to face questions as to possible limits to the corporate action and as to what other parties, if any, might avail themselves of this rationale to bring an action. For example, courts might refuse an action when management's main objective in seeking an injunction is to maintain corporate control. ${ }^{79}$ On the other hand, it might be entirely permissible to extend the action to parties which have a legitimate interest in maintaining a fair market value for the stock-such as a bank which holds a substantial block of the manipulated security as collateral on a loan, or a stock exchange on whose floor the manipulation is taking place. ${ }^{80}$ Stockholders, as well, might be permitted to bring derivative actions in the corporate name. ${ }^{81}$

75 See text accompanying note 78 infra.

70 H.R. Res. 363, 73d Cong., 2d Sess. (1934).

77 The private right to sue for damages was implied through $\$ 27$ in Kardon $v$. Vational Gypsum $C_{o}$. and other cases. See notes 20-22 supra and accompanying text.

78339 F.2d at 28. (Emphasis added.)

79 See text accompanying notes 34-35 supra.

so There is the possibility that management might employ misrepresentations or other deceptive practices to defeat a tender offer and thus retain its control. See Fleischer \& Mundheim, Corporate Acquisition by Tender Offer, 115 U. PA. L. Rev. $317,360-64$ (1967). The rationale expressed in this Comment might make injunctive relief available to the offeror.

81 Granting the corporation standing to seek an injunction in the situation presented in Studebaker by no means dictates that a stockholder suing derivatively be 
Though it may seem radical to confer upon a private party the same powers of enforcement as the SEC, it would advance the overall policies supporting section $10(\mathrm{~b})$ and rule $10 \mathrm{~b}-5$ "to keep the channels of interstate commerce . . . pure from fraudulent schemes, tricks, devices, and all forms of manipulation." 82 The current trend in the rapidly developing area of securities regulation is toward a liberal interpretation of the act to compel strict compliance with its requirements and the rules promulgated under it. The decisions ameliorating the impact of the purchaser-seller limitation in rule $10 \mathrm{~b}-5$, eliminating the need for privity between the defrauder and the defrauded and enjoining violations of the proxy rules, all interpret the law liberally to permit private actions to remedy the wrong done by a violation of the Exchange Act. It would not be a radical departure to grant injunctive relief to a corporation whose securities are being manipulated on the market.

granted standing. Several of the policy arguments in favor of giving standing to the corporation in the Studebaker situation would not be applicable to derivative suits - specifically, those which relate to management's greater access to relevant information. It might be decided, therefore, to relegate shareholders to their individual remedies if management refuses to bring suit in the corporate name. On the other hand, it might be argued that the "policing" function of the securities acts would be furthered by permitting the individual shareholder to sue derivatively on behalf of the corporation (and seek reimbursement from the corporate treasury if he is successful). Under the rationale proposed in this Comment for granting standing to the corporation where suit is instituted by management, there seems to be little reason to distinguish derivative suits which are similar to Studebaker, in that the relief sought is injunctive and the defendants are "outsiders." Where management is alleged to have engaged in the challenged activity, there exists the danger that "strike-suiters" will be bought off by management with corporate funds, thus further harming the corporation and defeating the "policing" function served by allowing corporate standing. Of course, it could be argued that it is in the latter class of cases that the derivative suit remedy is most necessary. And see FED. R. Crv. P. 23.1 (requiring court approval of all settlements of derivative suits).

82 Hooper v. Mountain States Sec. Corp., 282 F.2d 195, 202 (5th Cir. 1960), cert. denied, 365 U.S. 814 (1961). 